\title{
The role of the diffusion of oxygen in the respiration of rat diaphragm at different temperatures ${ }^{1}$
}

\author{
Frederick A. Fuhrman and Douglas A. Farr \\ Max C. Fleischmann Laboratories of the Medical Sciences, School of Medicine, \\ Stanford University, Palo Alto, California, USA
}

\begin{abstract}
KURZFASSUNG: Die Bedeutung der Sauerstoffdiffusion für die Atmung des Rattendiaphragmas bei verschiedenen Temperaturen. Es werden Ergebnisse vorgelegt, welche die Hypothese untermauern, daß die Respirationsrate von Hemidiaphragmen und Gewebescheiben in vitro eingeschränkt ist, weil der Sauerstoff die innersten Gewebeschichten nicht zu erreichen vermag. Die Errechnung der kritischen Gewebedicke nach WARBuRgs Formel erfordert die Einsetzung des Wertes für $\mathrm{QO}_{2}$, der ist aber unbekannt, da er ja selbst wiederum von der Dicke abhängt. Man kann diesem Dilemma nicht dadurch ausweichen, daß man dünnere Scheiben verwendet; denn das würde die Gewebe beschädigen und so den $\mathrm{QO}_{2}$ herabsetzen. Wir haben festgestellt, daß die Auftragung von $\log \mathrm{QO}_{2}$ gegen $1 / \mathrm{T}$ für das Rattendiaphragma eine gerade Linie ergibt zwischen $-6^{\circ}$ und $13,5^{\circ} \mathrm{C}$ und eine Linie mit dem halben Anstiegswinkel zwischen $18^{\circ}$ und $38^{\circ} \mathrm{C}$. Unter der Annahme, daß das Sauerstoffangebot über etwa $18^{\circ} \mathrm{C}$ unzureichend wird, werden Gleichungen gegeben für die Errechnung des $\mathrm{QO}_{2}$ bei den oben genannten Temperaturen. Die errechneten Daten stimmen mit den beobachteten Werten gut überein. Bei $33^{\circ} \mathrm{C}$ war der $\mathrm{QO}_{2}$-Wert höher bei einem Sauerstoffdruck von 2 Atmosphären als bei einem solchen von 1 Atmosphäre; dieser Sachverhalt steht in Ubereinstimmung mit den theoretischen Erörterungen.
\end{abstract}

\section{INTRODUCTION}

Most chemical and enzymatic reactions conform to the Arrhenius equation in which a straight line, with a slope proportional to $\mu$, is obtained when log of velocity is plotted as a function of the reciprocal of absolute temperature. On the other hand, for the oxygen consumption of rat diaphragm and slices of liver, plots of $\log \mathrm{QO}_{2}$ versus $1 / \mathrm{T}$ yield curves whose slopes diminish with increase in temperature below the thermal optimum. One explanation for the latter relationship is that these curves for respiration of tissue slices are not true representations of the relationship but are artefacts produced by inadequate oxygenation, and consequently low $\mathrm{QO}_{2}$, at the higher temperatures. Thus, at the higher temperatures the diffusion of oxygen into the tissue in vitro may limit the $\mathrm{QO}_{2}$ at temperatures approaching the optimum. We have tested this hypothesis and wish to report the results here.

1 This work was supported in part by a grant from the National Science Foundation. 


\section{METHODS}

Experiments at atmospheric pressure were performed by the direct method of WARBURG using diaphragm from Long-Evans rats of various sizes. The medium was Krebs (1950) Medium III and the gas phase was $100 \%$ oxygen. The tissue was prepared and the vessels filled in a cold room at $4^{\circ} \mathrm{C}$. The vessels were then placed on manometers and shaken at $120 /$ minute with a stroke length of $2 \mathrm{~cm}$ at various temperatures for 30 to 60 minutes after thermo-equilibration. Each vessel was used for only one temperature. Experiments at high pressures of oxygen were performed in a specially constructed differential manometric apparatus.

\section{RESULTS}

\section{Theoretical relationships}

W ARBURG (1923) showed that the limiting thickness, $d$, of a tissue slice that permits oxygen to reach the innermost layers is given by

$$
\mathrm{d}=\sqrt{8 \mathrm{C}_{0} \frac{\overline{\mathrm{K}_{\mathrm{D}}}}{\mathrm{QO}_{2}}}
$$

in which $\mathrm{d}=$ limiting thickness in $\mathrm{cm}, \mathrm{C}_{0}=$ oxygen concentration in the medium in atmospheres, $\mathrm{QO}_{2}=$ rate of oxygen consumption in $\mathrm{ml} / \mathrm{min} / \mathrm{ml}$ tissue, and $\mathrm{K}_{\mathrm{D}}=$ the Krogh diffusion coefficient in $\mathrm{cm} / \mathrm{atm} / \mathrm{min}$. The value of $\mathrm{QO}_{2}$ for insertion in Equation (1) is actually unknown. It is frequently assumed to be that found using "thin" slices, but actually may be much higher. One way of estimating the "true" value of $\mathrm{QO}_{2}$ is to measure $\mathrm{QO}_{2}$ as a function of temperature and to then calculate the "true" $\mathrm{QO}_{2}$ from an extrapolation of the straight part of the line obtained by plotting $\log \mathrm{QO}_{2}$ versus $1 / \mathrm{T}$. It is thus assumed that $\mu$ is constant with temperature and that as $\mathrm{QO}_{2}$ decreases with decrease in temperature a point is reached where the measured $\mathrm{QO}_{2}$ is the true one and the thickness of the tissue at that temperature and below must be less than limiting.

If we assume that the tissue slice is too thick for oxygen to diffuse to the innermost layer, and if we neglect the diffusion of oxygen from the edges of the tissue, then

$$
\mathrm{QO}_{2} \mathrm{E}=-\frac{\mathrm{d}}{\mathrm{D}} \mathrm{QO}_{2}^{\mathrm{T}} \quad \mathrm{D} \geq \mathrm{d}
$$

where $\mathrm{QO}_{2} \mathrm{E}=$ the $\mathrm{QO}_{2}$ obtained experimentally, $\mathrm{QO}_{2} \mathrm{~T}=$ the "true" $\mathrm{QO}_{2}, \mathrm{~d}=$ limiting thickness with respect to oxygen, and $D=$ the actual thickness. If

$$
\mathrm{D} \leq \mathrm{d} \text {, then } \mathrm{QO}_{2}{ }^{\mathrm{E}}=\mathrm{QO}_{2} \mathrm{~T}
$$

Equation (1) may be rewritten as

$$
\mathrm{d}=\sqrt{\frac{\mathrm{KC}_{0}}{\mathrm{QO}_{2}{ }^{\mathrm{T}}}}
$$

in which $\mathrm{K}$ is a constant including Krogh's diffusion constant $\left(K_{D}\right)$ and permits ex- 
pression of the rate of oxygen consumption per hour rather than per minute. It is equal to $480 \mathrm{~K}_{\mathrm{D}}$. Combining equations (2) and (4)

$$
\mathrm{QO}_{2} \mathrm{E}=\frac{\sqrt{\frac{\mathrm{KC}_{0}}{\mathrm{QO}_{2}^{\mathrm{T}}}}}{\mathrm{D}} \ldots \mathrm{QO}_{2}^{\mathrm{T}} \quad \mathrm{D} \geq \mathrm{d}
$$

If $\mathrm{D}$ and $\mathrm{C}_{0}$ are constant, then:

$$
\mathrm{QO}_{2}^{\mathrm{E}}=\mathrm{K}^{\prime} / \mathrm{QO}_{2}^{\mathrm{T}} \quad \mathrm{D} \geq \mathrm{d}
$$

where $\mathrm{K}^{\prime}=\sqrt{\mathrm{KC}_{0}}$. If, according to the Arrhenius equation, $\log \mathrm{v}$ or $\log \mathrm{QO}_{2}$, gives D

a straight line when plotted against $1 / \mathrm{T}$, then the equation for this line is:

$$
\log \mathrm{QO}_{2}^{\mathrm{T}}=\frac{-\mathrm{a}}{\mathrm{T}}+\mathrm{B}
$$

where $-\mathrm{a}=$ slope and $\mathrm{B}=$ intercept. Combining equations (6) and (7)

where $B^{\prime}=\operatorname{antilog} B$.

$$
\begin{aligned}
& \mathrm{QO}_{2}{ }^{\mathrm{E}}=\mathrm{K}^{\prime}\left(\mathrm{B}^{\prime} \mathrm{e}^{\frac{-a}{\mathrm{~T}}}\right)^{1 / 2} \quad \mathrm{D} \geq \mathrm{d} \\
& \log \mathrm{QO}_{2} \mathrm{E}=\log \mathrm{K}^{\prime} \mathrm{B}^{3 / 2}+\frac{-\mathrm{a}}{2 \mathrm{~T}}
\end{aligned}
$$

Hence, by equation (9) the slope of the line when $\log \mathrm{QO}_{2} \mathrm{E}$ is plotted vs. 1/T should be equal to $\frac{-a}{2}$ for $D \geq d$, and the slope should be equal to - a for $D \leq d$.

The result is that any respiring tissue that has a constant $\mu$ over a given range of low temperatures will have a sudden drop in the value of $\mu$ to one-half that value at the temperature where the actual thickness is equal to the limiting thickness. To calculate the expected values of $\mathrm{QO}_{2}$ of rat diaphragm at temperatures where $\mathrm{D} \geq \mathrm{d}$, assuming $\mu$ remains constant, equation (2) was modified in three ways to improve its accuracy. These modifications consisted of allowing for diffusion of oxygen from the cut edges of the hemidiaphragms as well as from the upper and lower surfaces, considering the fact that the diffusion constant of oxygen varies slightly with temperature, and accounting for the varying thicknesses of the individual diaphragms. The first two modifications changed the slope of the line slightly, while the third resulted in the break from $\mu$ to $\mu / 2$ occurring over a range of temperatures rather than abruptly. For purposes of calculation the hemidiaphragms were considered to be parallelpipeds with dimensions $\mathrm{D}=1.074 \mathrm{~mm}, \mathrm{~W}=5.33 \mathrm{~mm}$, and $\mathrm{L}=34.1 \mathrm{~mm}$, the means of actual values.

\section{Oxygen consumption at atmospheric pressure}

The $\mathrm{QO}_{2}$ of rat diaphragm was measured at temperatures between $-6^{\circ} \mathrm{C}$ and $38^{\circ} \mathrm{C}$. In each case the thickness was also measured. The experimental data are plotted in Figure 1 as points, each being the mean of values from 6 to 14 animals. The line is 
drawn through the points where they fall on a straight line (from $-6^{0}$ to $13.5^{\circ} \mathrm{C}$ ) and then extrapolated as a dashed line with the same slope (equal to $\mu$ of 13.000 ) to higher temperatures. The dotted line above $13.5^{\circ}$ represents values of $\mathrm{QO}_{2}{ }^{\mathrm{E}}$ calculated from a modified form of Equation 2. The excellent agreement between the experimental points and the calculated line supports the hypothesis that the $\mathrm{QO}_{2}$ of rat dia-

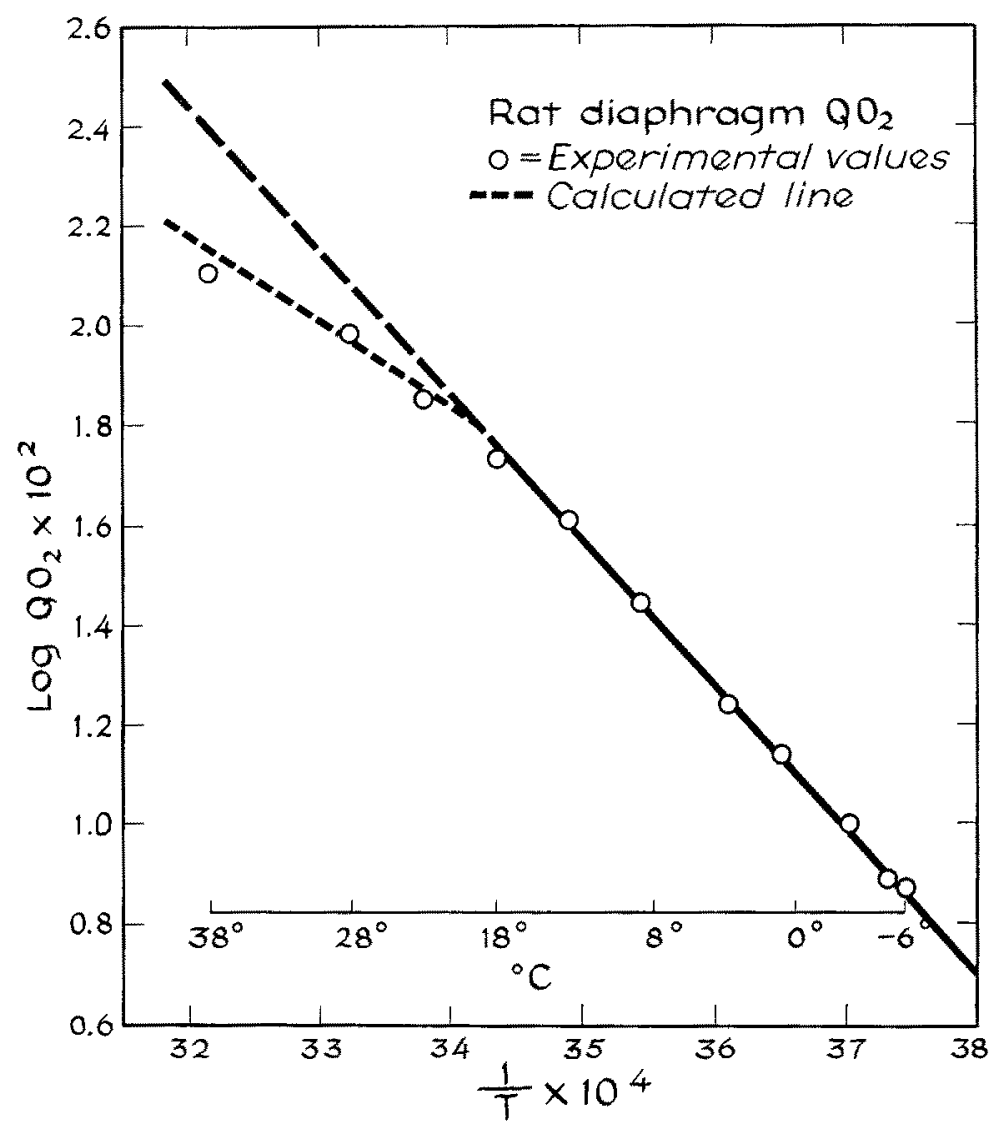

Fig. 1: $\mathrm{QO}_{2}$-values of rat hemidiaphragm

phragm is limited at higher temperatures by inadequate oxygenation. Furthermore, the line drawn through the experimental points from $18^{\circ}$ to $38^{\circ} \mathrm{C}$ has a slope approximately one-half that of the line berween $18^{\circ}$ and $-6^{\circ} \mathrm{C}$, as predicted from Equation (9).

Similar results have been obtained using mouse diaphragm and slices of rat liver.

\section{Oxygen consumption at bigh oxygen pressure}

The most conclusive test of hypothesis that inadequate oxygenation limits $\mathrm{QO}_{2}$ of tissue slices and diaphragm at temperatures above about $18^{\circ}$ would be to study 
the relationship between $\mathrm{QO}_{2}$ and temperature at high pressures of oxygen. The diffusion of oxygen through the liquid phase in the vessel introduces an additional problem. With yeast and bacteria, $\mathrm{QO}_{2}$ remains constant until the concentration of oxygen in the surrounding medium $\left(\mathrm{C}_{0}\right)$ falls to very low levels. Therefore the rate of shaking, which determines oxygenation of the medium, is not critical. With diaphragm, however, $\mathrm{QO}_{2}$ falls as soon as $\mathrm{C}_{0}$ in the surrounding medium falls. Therefore the rate of shaking must be adequate to maintain equilibrium between the gas phase and the liquid phase. At two atmospheres pressure we found that the rate of shaking, with $150 \mathrm{mg}$ (wet weight) of diaphragm per vessel, had to be over 100 per minute in order to provide oxygenation.

The $\mathrm{QO}_{2}$ of rat hemidiaphragm was measured at $18^{\circ}$ and $33^{\circ}$ and at oxygen pressures of 1 and 2 atmospheres. The data are given in Table 1. There is no doubt

Table 1

$\mathrm{QO}_{2}$ of rat diaphragm at high pressures of oxygen

Each value represents the mean of 4 to 6 samples

\begin{tabular}{|cccc|}
\hline Pressure & \multicolumn{2}{c|}{ Experimental $\mathrm{QO}_{2}$} & Calculated $\mathrm{QO}_{2}$ \\
$($ ATM $)$ & $18^{\circ} \mathrm{C}$ & $33^{\circ} \mathrm{C}$ & $33^{\circ} \mathrm{C}$ \\
\hline 1 & 0.60 & 1.18 & 1.15 \\
2 & 0.67 & 1.71 & 1.74 \\
\% Increase & 12 & 45 & 51 \\
at 2 ATM & & & \\
\hline
\end{tabular}

that a pressure of 2 atmospheres has little, if any, effect on $\mathrm{QO}_{2}$ at $18^{\circ}$, in agreement with the data in Figure 1 . However, at $33^{\circ}$, the $\mathrm{QO}_{2}$ at 2 atmospheres pressure was $45 \%$ higher than the $\mathrm{QO}_{2}$ at 1 atmosphere pressure. This agrees very closely with the calculated increase of $51 \%$. Thus, the effects of high pressure of oxygen on $\mathrm{QO}_{2}$ of diaphragm strongly support the hypothesis presented here.

\section{SUMMARY}

1. Data are presented to support the hypothesis that the respiration rate of hemidiaphragms and tissue slices is restricted in vitro because oxygen fails to reach the innermost layers of the tissue.

2. Calculation of limiting thickness from WARBURG's formula (Equation 1) requires use of a value for $\mathrm{QO}_{2}$, but the true value is unknown since it is in turn dependent upon thickness. The dilemma is not avoided by making thinner slices because this damages tissues and reduces the $\mathrm{QO}_{2}$.

3. We found that for rat diaphragm a plot of $\log \mathrm{QO}_{2}$ versus $1 / \mathrm{T}$ yields a straight line between $-6^{\circ}$ and $13.5^{\circ} \mathrm{C}$, and a line of half that slope from $18^{\circ}$ to $38^{\circ} \mathrm{C}$.

4. Equations are presented for calculating $\mathrm{QO}_{2}$ at these temperatures, assuming that oxygenation is incomplete above about $18^{\circ} \mathrm{C}$. The calculated values agree well 
with the observed values. Further, $\mathrm{QO}_{2}$ of diaphragm at $33^{\circ} \mathrm{C}$ was higher at an oxygen pressure of 2 atmospheres than 1 atmosphere in agreement with theoretical considerations.

\section{LITERATURE CITED}

Krebs, H. A., 1950. Body size and tissue respiration. Biocbim. biophys. Acta 4, 249-269.

WARBURG, O., 1923. Versuche an überlebendem Carcinomgewebe (Methoden). Biochem. Z. 142, $317-333$. 